UDC 378.2147:6148]:005.5

DOI: $10.31470 / 2415-3729-2019-9-128-141$

\title{
Problem of the Readiness of Cadets of Specialized Higher Educational Establishments of the State Emergency Service of Ukraine for a managerial activity
}

\section{Yuliia Panimash}

Senior lecturer of the Department of the Management in the Sphere of Civil Defense

Cherkasy Institute of Fire Safety named after Chernobyl Heroes of National University of Civil Defense in Ukraine

$\triangle$ 8, Onopriienko Str., Cherkasy, Ukraine, 18034

E-mail: hawaii-travel@ukr.net

ORCID:0000-0002-5337-6613

Date of receipt of the article: November 29, 2018

Article accepted for publication: February 21, 2019

\section{Проблема готовності курсантів профільних закладів вищої освіти ДСНС України до управлінської діяльності}

\section{Юлія Вікторівна Панімаш}

старший викладач кафедри менеджменту в сфері цивільного захисту Черкаський інститут пожежної безпеки імені Героїв Чорнобиля Національного університету цивільної оборони України

$\checkmark$ вул. Онопрієнко, 8, м. Черкаси, Україна, 18034

Дата надходження статті: 29 листопада 2018 р. Стаття прийнята до друку: 21лютого 2019 р.

\section{Abstract}

The article deals with theoretical aspects of a problem of the formation of the readiness of cadets of specialized higher educational establishments of the State Emergency Service of Ukraine for a managerial activity. 
On the basis of studied literature it was found out by the author that readiness for a managerial activity is considered as a complex, stable personal formation, expressing the aspirations of a specialist, on the basis of available professional knowledge, skills, professional orientation and personal qualities to successfully solve the tasks of management of personnel and a unit as a whole; it provides for the special organization of the educational process of future officers; the awareness of cadets and students about their reflection in the system of training for future activities.

It was determined that a managerial activity is a complex socio-psychological phenomenon. The components of the readiness of future specialists of the State Emergency Service of Ukraine for the management activity are determined as: a discipline, a self-organization and punctuality, a possession of an effective management style, an ability to clearly formulate tasks and goals, a possession of etiquette rules, an ability to conduct educational work, a communicative competence. It is also proved that technical, professional, psychological and pedagogical training of students influences the improvement of readiness for a managerial activity. It is theorized that graduates of specialized institutions of the State Emergency Service of Ukraine should be able to quickly take their bearings in emergencies and adapt to them, take initiative, be selfless and persistent in fulfilling their tasks, improve their professional skills, be able to assess the situation correctly and adequately, take managerial decisions and to be psychologically ready for extreme situations while carrying out operational activities and extinguishing fires.

It is determined that the cadets of specialized higher educational institutions of State Emergency Service of Ukraine strive for a self-improvement and a self-development, possess executive and communicative skills, and can confidently, timely and faithfully apply functions of planning, organization, motivation, control and coordination.

Key words: specialized establishment, higher educational establishment, managerial activity, readiness, psychological readiness, emergency situations, professional activity. 


\section{References}

1. Meljnyk, A.F., Obolensjkyj, O.Ju., Vasina, A.Ju. \& Ghordijenko, L.Ju. (2003). Derzhavne upravlinnja [Public administration]. In A.F. Meljnyk (Ed.) Kyiv: Znannja-Pres [in Ukrainian].

2. Derkach, A.A. (2004). Akmeologicheskie osnovyi razvitiya professional [Acmeological basis of professional development]. Moskva: MPSI [in Russian].

3. Dal, V.I. (1981). Tolkovyiy slovar tipovogo velikorusskogo yazyika [A glossary of the typical Great Russian language]. Moskva: Russkiy yazyik (Vol. 1, 699 p.) [in Russian].

4. Mojsejenko, A.O. Ghotovnistj naselennja Ukrajiny do dijaljnosti $\mathrm{v}$ informacijnomu suspiljstvi [The readiness of the Ukrainian population for activities in the information society]. Retrieved from https://www.isu.org.ua [in Ukrainian].

5. Bunjejev, T.V. (2002). Rozvytok ghotovnosti v molodykh oficeriv-prykordonnykiv do samostijnogho vykonannja posadovykh obov'jazkiv [Development of young officersfrontier guards' readiness to self-fulfillment of official duties]. Extended abstract of candidate's thesis. Khmeljnycjkyj: Nac. akademiji PVU [in Ukrainian].

6. Maslova, M.Gh., Trakaljuk, O.L., Debrenjuk, A.P., Volodarsjkyj, V.L. \& Krasnopoljskyj, A.L. (2012). Metody ocinky psykhologhichnykh jakostej oficeriv dlja vyznachennja rivnja ghotovnosti do upravlinsjkoji dijaljnosti [Methods of the officers' psychological qualities assessing for determining the level of their readiness for management activities]. Visnyk Kyjiv. nac. un-ta imeni Tarasa Shevchenka. Ser.: Vijsjkovo-specialjni nauky, 27, 30-33 [in Ukrainian].

7. Voljansjkyj, P.B. (2017). Pidvyshhennja rivnja pidghotovky kerivnykiv sfery cyviljnogho zakhystu za rakhunok rozvytku jikh kreatyvnykh jakostej [Improvement of the level of the civil protection sphere leaders' training due to the development of their creative qualities]. Visnyk Naukovo-metodychnogho centru navchaljnykh zakladiv sfery cyviljnogho zakhystu, 26, 21-27 [in Ukrainian]. 
8. Vovk N.P. \& Dobroskok I.I. (2009). Rozvytok profesiino vazhlyvykh yakostei maibutnoho pratsivnyka derzhavnoho pozhezhnoho nahliadu MNS Ukrainy u profesiinii pidhotovtsi: akmeolohichnyi aspekt [Development of professionally important qualities of the future employee of the state fire department of the Ministry of Emergencies in professional training: acmeological aspect]. Humanitarnyi visnyk DVNZ «Pereiaslav-Khmelnytskyi derzhavnyi pedahohichnyi universytet imeni Hryhoriia Skovorody», 18, 25-29 [in Ukrainian].

\section{Вступ}

Підвищення якості освіти $€$ однією 3 актуальних проблем не тільки для України, але і для всього світового співтовариства. Вирішення цієї проблеми пов'язано 3 модернізацією змісту освіти, оптимізацією засобів i технологій організації освітнього процесу та, звичайно, переосмисленням мети і результату освіти.

Сучасний етап розвитку українського суспільства характеризується ускладненням вимог до рівня готовності майбутніх фахівців до професійної діяльності, модифікацією засобів управлінської комунікації, якісними змінами у визначенні стратегічних принципів та пріоритетних цілей управління. Ці процеси ставлять на перший план не лише проблему управління, але i вдосконалення шляхів та технологій здійснення суб'єктами управлінської діяльності.

Під феноменом управління розуміємо цілеспрямовану дію суб'єкта управління на об'єкт управління. До загальних функцій управління належать: планування, організування, мотивування, контроль, координація. Відповідно, управління буде успішним завдяки вмінням фахівця своєчасно та вірно застосовувати означені функції.

А. Мельник, О. Смоленський, А. Васіна, Л. Гордієнко зазначають, що управлінська діяльність $€$ сукупністю вироблених історичним досвідом, науковим пізнанням i талантом людей навичок, умінь, способів, засобів доцільних вчинків і дій людини у сфері управління. Вона вирізняється 
інтелектуальним характером, що виражається в спрямованості на вироблення, прийняття та практичну реалізацію управлінських рішень, покликаних змінювати у бажаному напрямі стан і розвиток суспільних процесів, свідомість, поведінку і діяльність людей (Мельник, 2003).

Деякі аспекти формування управлінських якостей майбутніх офіцерів висвітлені у публікаціях ученихпедагогів: О. Барабанщиков, В. Звягінцев, М. Новожилов, О. Матеюк, Л. Мерзляк, М. Нещадим, О. Сафін, В. Синьов, В. Стасюк, В. Бойко, І. Грязнов, Н. Давидов, Д. Іщенко, Е. Коротков, В. Маслов, В. Пліско, Р. Санжаєва, В. Ягупов та ін. Проблеми формування готовності майбутніх фахівців до різних видів професійної діяльності, зокрема управлінської, частково розглянуті у працях В. Барка, М. Дяченка, А. Деркача, А. Ліненка, Л. Кандибовича, В. Моляко, О. Мороза та ін. Водночас варто констатувати, що проблема формування готовності до управлінської діяльності майбутніх фахівців ДСНС України не була предметом цілісного аналізу.

Аналіз робіт відомих авторів підтверджується актуальність дослідження готовності до професійної діяльності. У цьому контексті актуальним залишається визначення готовності до управлінської діяльності.

Мета статті - дослідити проблему готовності курсантів профільних закладів вищої освіти ДСНС України до управлінської діяльності. У процесі дослідження були поставлені такі завдання: встановити перелік здібностей, що впливають на готовність до управлінської діяльності майбутніх фахівців ДСНС України; визначити фактори, що впливають на вдосконалення готовності до управлінської діяльності.

\section{Матеріал і методи досліджень}

Методи дослідження: теоретичні (аналіз та узагальнення психолого-педагогічної літератури), емпіричні (спостереження, порівняння).

\section{Результати та їх обговорення}

Сьогодні система професійної підготовки курсантів закладів вищої освіти ДСНС України не в повному обсязі 
враховує існуючі реалії. У багатьох випускників управлінська компетентність знаходиться на низькому рівні, який не дозволяє ефективно вирішувати професійні задачі, що негативно впливає на їх професійну діяльність.

Сучасні умови службової діяльності підрозділів оперативно-рятувальної служби цивільного захисту ДСНС України вимагають від рятувальників вміння швидко реагувати на поставлені задачі, приймати нестандартні рішення та передбачати наслідки прийнятих рішень. Адже складність ліквідації надзвичайних ситуацій обумовлена наступними аспектами:

- психологічна готовність до небезпек;

- спеціальна професійна підготовка;

- теоретичні та практичні навички;

- правильність прийняття рішень в умовах обмеженого часу;

- тактика дій з ліквідації надзвичайних ситуацій.

Як відомо, виконання завдань з ліквідації надзвичайних ситуацій в значній мірі визначається роботою оперативнорятувального підрозділу і багато в чому залежить від особистісних якостей, професійної та психологічної підготовленості, готовності до діяльності в екстремальних ситуаціях рятувальників. Логічно, що недостатня професійна та управлінська готовність співробітників може призвести до зриву виконання ними службового завдання, звести нанівець їх професійні знання, вміння і навички. Тому успіх діяльності співробітників ОРС ЦЗ в умовах впливу несприятливих факторів при виконанні службових завдань багато в чому залежить від їх готовності до такої діяльності.

Відповідно, випускники профільних закладів ДСНС України повинні вміти швидко орієнтуватися під час надзвичайних ситуацій та адаптовуватися до них, бути ініціативними, самовідданими та наполегливими під час виконання поставлених задач, удосконалювати свої професійні здібності, вміти правильно та адекватно оцінювати обстановку, приймати управлінські рішення та бути психологічно готовими до екстремальних ситуацій під час проведення оперативно-розшукової роботи та гасіння пожеж. 
В. Даль трактує дефініцію «готовність» як стан чи ознаку готового і вважає, що підготовлена людина є не лише готовою до дії, а може і хоче її виконати, виявляє позитивне ставлення до тієї чи іншої діяльності. Автор також зазначає, що готовність особистості до дії, передусім, залежить від психологічної установки на виконання діяльності, яка вимагає певних зусиль (Толковый словарь типового великоруського языка, 1981). А. Деркач визначає поняття «готовність» як цілісний прояв властивостей особистості, виділяює три компоненти у іï структури: пізнавальний, емоційний, мотиваційний. На його думку, розвиток готовності означає організацію системи навчання 3 накопичення громадської інформації, відносин, поведінки та іншої подібної інформації, яка, активізуючись, може надавати індивіду можливість ефективно виконувати свої функції (Деркач, 2004). Отже, володіння готовністю вказує на позитивне ставлення до тієї чи іншої діяльності, можливість ефективно виконувати певні функції.

Ряд науковців (А. Маркова, А. Мойсеєнко, В.Семіченко та ін.) визначають готовність до професійної діяльності як психічний стан, і виділяють: а) операційну готовність моментальну передстартову активізацію людини, iii включення в діяльність з необхідним рівнем активності, б) функціональну готовність - усвідомлення людиною своїх цілей, оцінку наявних умов, визначення найбільш імовірних способів діяльності, в) особистісну готовність, яка включає пролонговану високу активність людини при включені в трудовий процес, прогнозування необхідності і розподілу в часі мотиваційних, вольових, інтелектуальних зусиль, оцінку імовірності досягнення життєвих успіхів через діяльність.

У сучасних дослідженнях активно розглядаються проблеми формування психологічної готовності. Так, А. Мойсеєнко виокремлює такі головні характеристики психологічної готовності, як:

- суттєва передумова цілеспрямованої діяльності, іiі регуляції, стійкості та ефективності, яка допомагає людині успішно виконувати свої обов'язки, правильно використовувати знання, досвід, особистісні якості, 
зберігати самоконтроль і перебудовувати свій спосіб дій при появі непередбачених перешкод (С. Максименко, О. Пелех);

- стійка характеристика особистості, яка в конкретному своєму прояві виражається в готовності до професійної діяльності, психічний стан особистості, який виражається в здібності приймати самостійні рішення при виникненні складних професійних завдань, оцінці своїх можливостей в їх співвідношенні до майбутніх труднощів і досягненні певних результатів, передачі своїх знань іншим (Т. Іванова);

- відносно стійкий стан, що визначається базовими (зокрема характерологічними) i програмованими (мотиваційними та інтелектуальними) властивостями особистості і проявляється в активно-позитивному відношенні до професії та у сформованій професійній самосвідомості (Е. Корабліна);

- сформована спрямованість на професійну діяльність, настанова на роботу, наявність інтересу до предмета діяльності, потреба в самоосвіті в цій галузі, розвинуте професійне мислення (В. Сластьонін);

- цілеспрямований вияв особистості, який включає систему професійних знань, навичок, умінь, потреб, мотивів, психологічних якостей, настанов і станів особистості, який дозволяє успішно включатися в професійну діяльність і виконувати іiі оптимальним для даної діяльності і даної особистості чином (П. Горностай);

- потреба в діяльності, необхідність усвідомлення відповідності особистісних якостей вимогам діяльності, усвідомлена мотивація особистісних прагнень до даної спеціальності (О. Мороз);

- поєднання багатьох i дуже різноманітних взаємопов'язаних рис, а не окрема якість людини, не окрема риса особистості (А. Смірнов) (Мойсеєнко А., 2004: 232).

Отже, поняття «психологічна готовність» тлумачиться науковцями як суттєва передумова цілеспрямованої 
діяльності, іiі регуляції, стійкості та ефективності; психічний стан особистості, стійкий стан, що визначається базовими i програмованими властивостями особистості; спрямованість на професійну діяльність; система професійних знань, навичок, умінь, потреб, мотивів, психологічних якостей, настанов і станів особистості; потреба в діяльності; поєднання багатьох і дуже різноманітних взаємопов'язаних рис тощо.

На основі аналізу сучасної психолого-педагогічної літератури у нашому дослідженні визначено поняття «готовність курсантів профільних закладів вищуої освіти ДСНС України до управлінської діяльності» складне інтегроване особистісне утворення, яке $\epsilon$ результатом професійної підготовки та виявляється у ступені сформованості знань, умінь, навичок, мотивів і цінностей курсантів, їх управлінських якостей (організаційних, лідерських, комунікативних, соціально значущих), що обумовлюють швидку адаптацію до виконання службових обов’ язків у надзвичайних ситуаціях та успішну професійну діяльність оперативно-рятувальних підрозділів.

Аналіз сучасної психолого-педагогічної літератури дав змогу зробити висновок про те, що більшість дослідників (В. Барко, С. Будник, Н. Кисельова, А. Клімова, С. Рибніков, P. Троцький, В. Уліч та ін.) серед компонентів готовності до управлінської діяльності виокремлюють мотиваційноціннісний, когнітивний (гностичний, змістовий) $i$ емоційно-вольовий компоненти. Окрім того, кількість структурних компонентів варіюється від двох до восьми. Два компоненти готовності до управлінської діяльності звужують сутнісні показники цього поняття, а значна кількість компонентів ускладнюють діагностування рівнів сформованості досліджуваного феномена.

3 урахуванням специфіки майбутньої професійної діяльності фахівців оперативно-рятувальної служби цивільного захисту України у структурі досліджуваного феномена виокремлено наступні провідні компоненти i показники: 
- мотиваційно-цุіннісний - наявність професійно значущих установок на управлінську діяльність, усвідомлення їі цінностей);

- когнітивно-діяльнісний - володіння системою професійних знань (основних нормативно-правових актів, інструкцій, посадових обов'язків та інших документів; мовно-комунікативних; конфліктологічних; психолого-педагогічних, навчально-методичних), умінь, навичок майбутньої управлінської діяльності (самостійно визначати цілі й завдання діяльності підрозділу, прогнозувати можливі результати управлінської діяльності, приймати оптимальні рішення і втілювати їх в життя);

- емоційно-вольовий - уміння контролювати свої емоції, здатність працювати в екстремальних умовах, уміння встановлювати дружні стосунки, здатність мобілізувати підлеглих на виконання прийнятих рішень;

- рефлексивно-особистісний - уміння адекватно оцінювати досягнуті результати, коригувати та розбудовувати діяльність підлеглих і власну діяльність; розвиток організаційних, лідерських, комунікативних, соціально значущих якостей.

До складових готовності до управлінської діяльності курсантів профільних закладів вищої освіти ДСНС України віднесено наступні здатності, вміння та якості:

- дисциплінованість;

- самоорганізація та пунктуальність;

- володіння ефективним стилем управління;

- вміння чітко формулювати задачі та цілі;

- володіння правилами етикету;

- вміння проводити виховну роботу;

- володіти комунікативною компетентністю.

Цікавою є думка Т. Бунєєва про те, що готовність молодих офіцерів прикордонників до самостійного виконання посадових обов'язків можна підвищити за таких умов: орієнтація самовиховання офіцерів на розвиток самостійності; підвищення рівня внутрішньої мотивації молодих офіцерів до самостійного розв'язання поставлених 
завдань; вдосконалення змісту і методики організації педагогічної діяльності офіцера підрозділу (Бунєєв, 2002: 5). Успішності управлінської діяльності офіцера, на думку M. Маслової, О. Тракалюка, А. Дебренюка, В. Володарського, А. Краснопольского, сприяють такі психологічні якості: висока професійна компетентність, управлінська підготовленість, нестандартність мислення, що проявляється у здатності віднаходити нові рішення, самостійність і відповідальність, прагнення до успіху, уміння організувати свою роботу й роботу підлеглих, вимогливість, контроль і турбота про підлеглих, комунікативність, емоційна врівноваженість, стресостійкість, чесність і порядність, постійне самовдосконалення (Маслова, 2012: 30-31).

П. Волянський на підставі аналізу дій органів управління та сил цивільного захисту під час реагування на надзвичайні ситуації робить висновок, що в деяких випадках рішення керівниками приймалися на основі вже раніше відпрацьованих алгоритмів дій, у яких не завжди враховувалися особливості конкретної надзвичайної ситуації, можливі варіанти іï розвитку, спостерігався догматизм та шаблонність у прийнятті рішень, нездатність до всебічної оцінки обстановки, відсутність творчого підходу під час виконання завдань (Волянський, 2017: 21-27). Автор доводить необхідність формування у площині якісної підготовки керівного складу сфери цивільного захисту єдиної державної системи цивільного захисту креативності як «поєднання професійних і особистісних якостей людини, що проявляються під час іiі практичної діяльності, результатом якого є генерація нових, оригінальних ідей, рішень, що дозволяє найбільш ефективно вирішувати завдання колективом або людиною у складних умовах обстановки (Волянський, 2017: 21-27)». Погоджуємо 3 автором, що креативність $є$ основною якістю сучасного управлінця i керівника.

\section{Висновки}

Управлінська діяльність фахівців у системі ДСНС України характеризується багатофункціональністю, динамічністю, особливими умовами напруженості під час 
надзвичайних ситуацій, чітким керуванням діями, їх злагодженістю та узгодженістю, адже пов'язана 3 безперервним вирішенням нагальних проблем, завдань управлінського спрямування. Відповідно, курсанти профільних закладів вищої освіти ДСНС України повинні прагнути до самовдосконалення та саморозвитку, володіти виконавчими та комунікативними якостями, а також впевнено, своєчасно та вірно застосовувати функції планування, організування, мотивування, контролю та координації.

\section{Література}

1. Державне управління: навч. посіб. / А.Ф. Мельник, О.Ю. Оболенський, А.Ю. Васіна, Л.Ю. Гордієнко; за ред. А.Ф. Мельник. Київ : Знання-Прес, 2003. 343 с. (Вища освіта XXI століття)

2. Деркач А.А. Акмеологические основы развития профессионала. Москва : МПСИ, 2004. 752 с.

3. Даль В. И. Толковый словарь типового великорусского языка, 8-е изд. Москва: Русский язык, 1981. Т. 1. А-3. 699 c.

4. Мойсеєнко А.О., Готовність населення України до діяльності в інформаційному суспільстві. Інформаційне суспільство. Шлях Украӥни. 2004. С. 232.

5. Бунєєв Т. В. Розвиток готовності в молодих офіцерівприкордонників до самостійного виконання посадових обов'язків : автореф. дис. на здобуття наук. ступеня канд. пед. наук : 20.02.02. Хмельницький : Вид-во Нац. академії ПВУ, 2002. 18 с.

6. Маслова М. Г., Тракалюк О.Л., Дебренюк А.П., Володарський В.Л., Краснопольский А.Л., 2012. Методи оцінки психологічних якостей офіцерів для визначення рівня готовності до управлінської діяльності. Вісник Київ. нач. ун-та імені Тараса Шевченка. Сер.: Військово-спеціальні науки. Вип. № 27. C. 30-33.

7. Волянський, П. Б., 2017. Підвищення рівня підготовки керівників сфери цивільного захисту за рахунок 
розвитку їх креативних якостей. Вісник Науковометодичного центру навчальних закладів сфери цивільного захисту. № 26. С. 21-27.

8. Вовк Н.П., Доброскок I.I. Розвиток професійно важливих якостей майбутнього працівника державного пожежного нагляду МНС України у професійній підготовці: акмеологічний аспект. Гуманітарний вісник ДВНЗ «Переяслав-Хмельницький державний педагогічний університет імені Григорія Сковороди» : збірник наукових праць. Переяслав-Хмельницький, 2009. Вип. 18. 25-29.

\section{Панімаш Ю. В}

\section{Проблема готовності курсантів профільних закладів} вищої освіти ДСНС України до управлінської діяльності

\section{Анотація}

У статті розглядаються теоретичні аспекти проблеми формування готовності курсантів профільних вищих закладів ДСНС України до управлінської діяльності.

На основі дослідженої літератури з'ясовано, що готовність до управлінської діяльності розглядається як складне, стійке особистісне утворення, що виражає прагнення фахівця, на основі наявних професійних знань, умінь, професійної спрямованості й особистісних якостей успішно вирішувати завдання 3 управління особовим складом і підрозділом у цілому; передбачає спеціальну організацію навчально-виховного процесу майбутніх офіцерів; усвідомлення курсантами та студентами відображення їх у системі підготовки до майбутньої діяльності.

Ключові слова: профільний заклад, заклад вищої освіти, управлінська діяльність, готовність, психологічна готовність, надзвичайні ситуації, професійна діяльність, управлінська діяльність. 


\section{Панимаш Ю.В.}

Проблема готовности курсантов профильных учреждений высшего образования ГСЧС Украины к управленческой деятельности

\section{Аннотация}

В статье рассматриваются теоретические аспекты проблемы формирования готовности курсантов профильных высших учебных заведений ГСЧС Украины к управленческой деятельности.

На основе исследованной литературы установлено, что готовность к управленческой деятельности рассматривается как сложное, устойчивое личностное образование, выражающее стремление специалиста, на основе имеющихся профессиональных знаний, умений, профессиональной направленности и личностных качеств успешно решать задачи по управлению личным составом и подразделением в целом ; предусматривает специальную организацию учебновоспитательного процесса будущих офицеров; осознание курсантами и студентами отражения их в системе подготовки к будущей деятельности.

Ключевые слова: профильный заведение, учреждение высшего образования, управленческая деятельность, готовность, психологическая готовность, чрезвычайные ситуации, профессиональная деятельность, управленческая деятельность. 